\title{
Evaluation of Yamuna Water Quality by Physical, Chemical and Biological Indexes
}

\author{
Bhawna Varshney $^{1}$, Amar Dhariwal ${ }^{2}$ \\ ${ }^{1}$ Department of Chemistry B.S.A. College, Mathura-281004 (India) \\ bhawnavarshney95@gmail.com \\ ${ }^{2}$ Department of Physics KR College, Mathura -281004(India) \\ kumarkrc@gmail.com
}

\begin{abstract}
Water is the basic necessity for the functioning of all life forms that exist on earth. It is safe to say that water is the reason behind earth being the only planet to support life. It is vital for the survival of living organisms, major ecosystems as wall as for human health, food production and economic development. It is universal fact that the life first arose in aquatic environment. Even today water is major consideration for technological, industrial, cultural, social-economic development to Hindu Mythodology river Yamuna is considered as one of the most sacred rivers.In this study water quality of river Yamuna was assessed from different points with regular intervals in every month during June 2019 to May 2020. The different physico-chemical parameters like temperature, pH, turbidity, $\mathrm{DO}, \mathrm{COD}, \mathrm{BOD}, \mathrm{TDS}$, total hardness, $\mathrm{Cr}, \mathrm{Fe}, \mathrm{Cd}, \mathrm{Pb}, \mathrm{Ni}, \mathrm{Mn}, \mathrm{Zn}$, and $\mathrm{Cu}$, were analysed from the Yamuna Water sample. During the course of analysis it was observed that there was marked variation in different parameters at different sample collection points. On the bases of this study we conclude that Yamuna river water is highly polluted and its quality is not good for irrigation as well as for aquatic life of organisms.
\end{abstract}

Keywords: Physico-Chemical analysis, electrical conductivity, biochemical oxygen demand, total dissolved solids, combined oxygen demand, drainage system, effluents.

\section{Introduction}

The quality of water is of vital concern for mankind since it is directly linked with human welfare. Water is a vital natural sources for a multiplicity of purpose such as drinking, domestic use, industrial cooling, power generation, agriculture, transportation and waste disposal. Rivers in general are considered tobe one of the most important resource for man. India has a rich river system, but rivers are exploited by every use. The monitoring data of the central pollution board show that most of the Indian river are contaminated by coliform bacteria and can be potential risk for health (Aranzo R.M, 1989) due to fast industrialization, urbanization and other developmental activities most of our rivers have been found to highly polluted. Even presence of heavy metals in water also have great impact on the enzymatic activity of Yamuna river soil (RanjuSharma et.al. 2020). Survey reveals that many river receive millions of litre of sewage, domestic waste, industrial effluents, land and agricultural drainage etc. These effluents cause degradation of water quality (Rao et.al. 1999)

The study of water quality of different rivers in India by Gill et.al. (1993), Sanjay et.al. (1990), Athappanet.al. (1992), Madhysthaet.al. (1996), Sreenivasa Rao et.al. (1999), Doctor et.al. (1998), Jain p (2009), Anil Kumar Mishra (2010), Maninder Kaur Dhillon (2013), C. Sharma et.al. (2017), Anima Upadhyayet.al. (2014), J. Pandayet.al. (2017), E. Siddiqui (2019) have shown remarkable pollution level. The discharge of untreated domestic and industrial effluents have severely affected the quality of river Yamuna Chadetrik Rout (2017).

Quantitative study of physico chemical condition of river Yamuna at Mathura is quite essential Dhillonet.al. (2013),
Fulekor and Dave (1983), Bilal Bhat et.al. (2018) Rachanaet.al. (2015), A Yadav et.al. (2019).

As it is well known that waste water effluents have so many pollutants and they show very harmful impact on river water Akporet.al. (2014). For physico chemical Analysis water samples were collected from different sites of river Yamuna.

\section{Material and Method}

Water samples were collected every month from specific locations during June 2019 to May 2020. The collected samples were analysed for various physico Chemical treatment as recommended by APHA (1995). Temperature and dissolved oxygen (DO) were measured at the sampling spot, BDH/AR grade reagents, double distilled water and borosilglass wares were used throughout the work. Temperature was measured by Celsius thermometer. $\mathrm{pH}$ and turbidity were measured by digital $\mathrm{pH}$ meter (type-325) and digital Nephelo-turbidity meter (type-132) respectively. Dissolved Oxygen (DO) was measured by digital DO meter (Model METZ192M). Chemical Oxygen demand (COD) was measured by dichromate reflux method. BOD was estimated by incubating the sample at $20^{\circ} \mathrm{C}$ for few days. TDS was estimated by digital TDS meter (METZ-701), Total hardness was determined by volumetric titration (E DTA method). Metal were estimated by atomic absorption spectrophotometer (AAS) with a Perkin-Elmer model-2380 instrument using Perkinelmer hollow cathode lamp as light sources sulphates was estimated by UV-VIS Spectrophotometer (type-118), chloride was estimated by volumetric titration with $\mathrm{AgNO}_{3}$. Alkalinity was determined by volumetric titration preliminary. Digestion of the water samples were necessary to release the metal associated with suspended matter and colloidal organic matter (chakrabortyet.al. 1987), (Subramanian and Meranger 1979) 


\section{Result and Discussion}

The range of results of various physico-Chemical parameters obtained during the analysis has been given in table- 1 .

Table 1: Range of results of various parameters at different specific sites of river Yamuna

\begin{tabular}{|c|c|c|}
\hline S.No. & Parameters & Range \\
\hline $1-$ & Temperature $\left({ }^{0} \mathrm{C}\right)$ & $10-24$ \\
\hline $2-$ & $\mathrm{pH}$ & $6.8-7.6$ \\
\hline $3-$ & Electrical conductivity $(\mathrm{mhos} / \mathrm{cm})$ & $1050-1600$ \\
\hline $4-$ & Dissolved Oxygen $(\mathrm{mg} / \mathrm{L})$ & $1.15-2.30$ \\
\hline $5-$ & Chemical Oxygen demand $(\mathrm{mg} / \mathrm{L})$ & $25-63$ \\
\hline $6-$ & Biochemical Oxygen demand $(\mathrm{mg} / \mathrm{L})$ & $15-28$ \\
\hline $7-$ & Chlorides $(\mathrm{mg} / \mathrm{L})$ & $546-604$ \\
\hline $8-$ & Sulphates $(\mathrm{mg} / \mathrm{L})$ & $262-450$ \\
\hline $9-$ & Total alkalinity $(\mathrm{mg} / \mathrm{L})$ & $150-250$ \\
\hline $10-$ & Total hardeness $(\mathrm{mg} / \mathrm{L})$ & $790-1500$ \\
\hline $11-$ & Total dissolved solids (mg/l) & $1300-2500$ \\
\hline
\end{tabular}

The range of concentration of various heavy metals obtained during the analysis has been given in table (2).
Table 2: Range of Concentration of Various Heavy Metals

\begin{tabular}{|c|c|c|}
\hline S. No & Heavy metals (mg/L) & Range \\
\hline $1-$ & $\mathrm{Cr}$ & $0.065-0.210$ \\
\hline $2-$ & $\mathrm{Fe}$ & $1.004-1.079$ \\
\hline $3-$ & $\mathrm{Cd}$ & $0.050-0.079$ \\
\hline $4-$ & $\mathrm{Pb}$ & $0.061-0.095$ \\
\hline $5-$ & $\mathrm{Ni}$ & $0.219-0.415$ \\
\hline $6-$ & $\mathrm{Mn}$ & $0.062-0.100$ \\
\hline $7-$ & $\mathrm{Zn}$ & $2.899-5.452$ \\
\hline $8-$ & $\mathrm{Cu}$ & $1.501-1.900$ \\
\hline
\end{tabular}

The comparison of concentration of various heavy metals at the intervals of month is given in figure 1 and 2 .

Value of concentration of heavy metals shown in fig 1
\begin{tabular}{|c|c|c|c|c|c|c|c|}
\hline \multicolumn{2}{|c|}{ Value of Concentration of Heavy Metals shown in Fig 1} \\
\hline Metals & June & August & October & December & February & April \\
\hline $\mathrm{Cr}$ & 0.21 & 0.065 & 0.085 & 0.14 & 0.181 & 0.198 \\
\hline $\mathrm{Cd}$ & 0.079 & 0.05 & 0.06 & 0.065 & 0.071 & 0.076 \\
\hline $\mathrm{Pb}$ & 0.095 & 0.061 & 0.068 & 0.072 & 0.078 & 0.083 \\
\hline $\mathrm{Ni}$ & 0.415 & 0.219 & 0.235 & 0.246 & 0.352 & 0.41 \\
\hline $\mathrm{Mn}$ & 0.1 & 0.062 & 0.073 & 0.078 & 0.082 & 0.093 \\
\hline
\end{tabular}

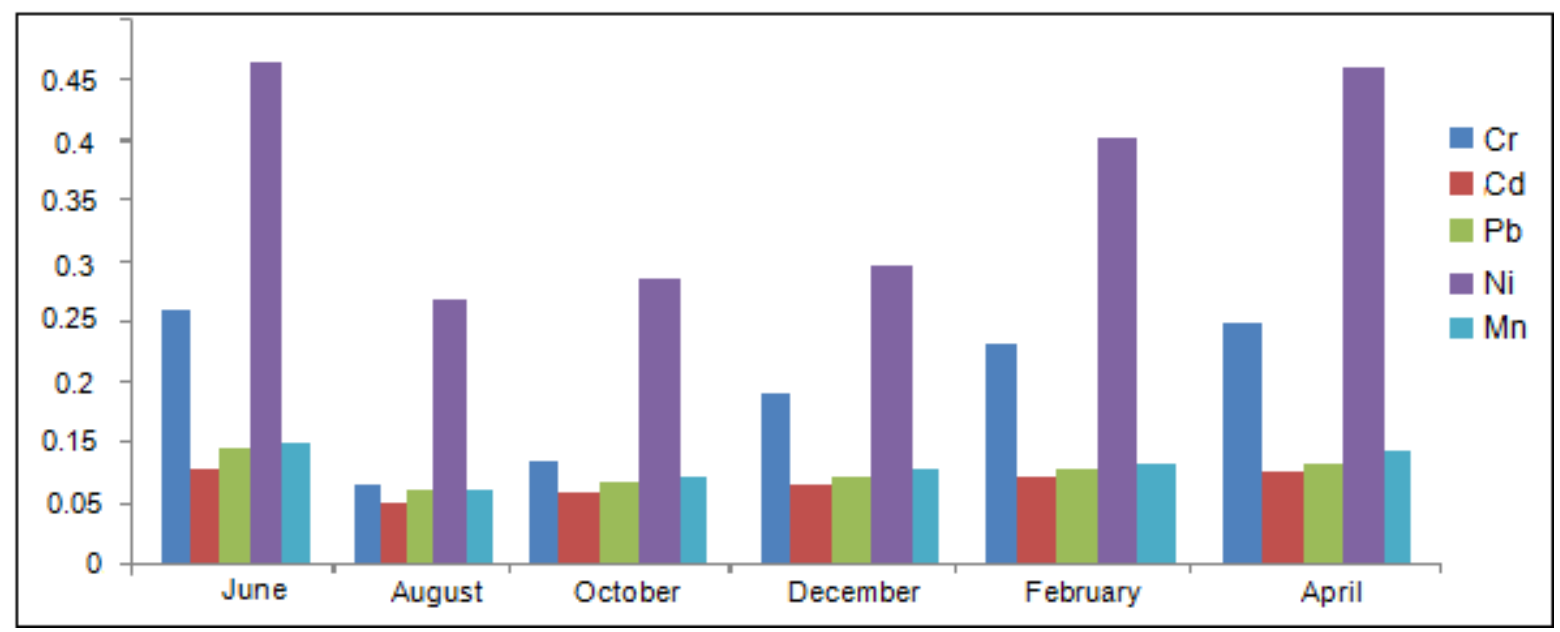

\begin{tabular}{|c|c|c|c|c|c|c|}
\hline \multicolumn{6}{|c|}{ Values of Concentration of Heavy Metals shown in Fig 2} \\
\hline Metals & June & August & October & December & February & April \\
\hline $\mathrm{Fe}$ & 1.079 & 1.004 & 1.012 & 1.022 & 1.035 & 1.056 \\
\hline $\mathrm{Cu}$ & 1.9 & 1.501 & 1.522 & 1.623 & 1.789 & 1.812 \\
\hline $\mathrm{Zn}$ & 5.452 & 2.899 & 3.486 & 3.893 & 4.521 & 5.021 \\
\hline
\end{tabular}

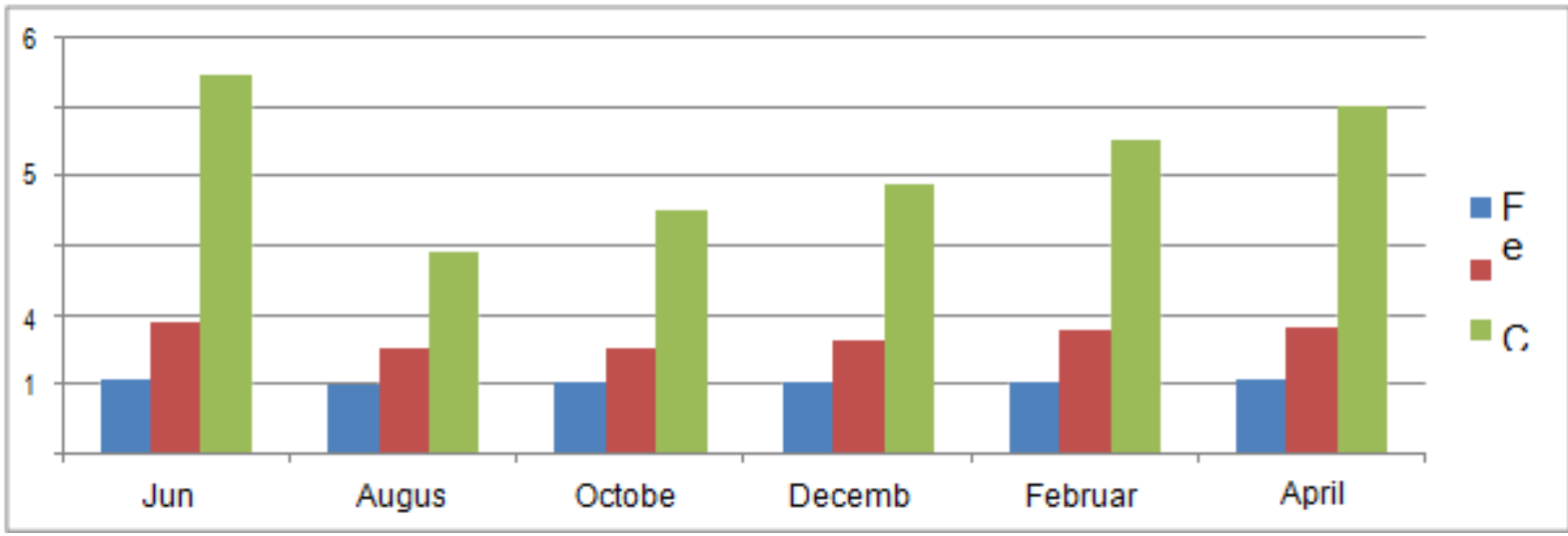

The concentration of $\mathrm{Cr}, \mathrm{Cd}, \mathrm{Ni}, \mathrm{Pb}$ and $\mathrm{Mn}$ were recorded beyond the permissible limit. The higher concentration of chromium metal in river water was due to the supply of effluents chromplating work, which is running on large scale in Mathura City. Some parameter like $\mathrm{pH}$, DO and concentration of same metals like $\mathrm{Fe}, \mathrm{Mn}, \mathrm{Ni}$, were found 
under tolerance limit. The chromium metal is carcinogenic, tetratogenic, and mutagenic element. The higher concentration of heavy metal like $\mathrm{Cr}, \mathrm{Cu}$ is harmful for aquatic orgnisms. On the other hand $\mathrm{Mn}$ is very important micronutrient for aquatic environment.

\section{Conclusion}

On the basis of above given information and analysis we can conclude that the pollution creating parameters have variable value due to ecological conditions as well as due to qualities and quantity of small scale industries and large scale of domestic waters. Almost all the parameters, except few were found to be beyond permissible limits. The significant pollution observed in Yamuna river water due to dropping of huge quantity of domestic sewage and industrial effluents discharge through nallahs into river Yamuna. There are approximate 50 nallahs which drop sewage and industrial waste into river Yamuna from different part of the city.

The high level of conductivity, turbidity, sulphates, chlorides, TDS, Hardness, $\mathrm{Ni}, \mathrm{Zn}, \mathrm{Pb} \mathrm{Cd}$ values at different sampling sites are definitely harmful to aquatic life of organisms as well as for irrigation and domestic purpose. A continuous monitoring at the river water for various parameters would be done (Sarma. D. 2011, CPCB 2006).

\section{Acknowledgement}

Author is thankful to the principal B.S.A College, Mathura for providing necessary facilities during the work.

\section{References}

[1] Aranzo R.M. Relation between aeromonas and faecalcoliforms in fresh water, J.appl. Bact. 67, 213217 (1989)

[2] Rao, S.A. Ramamohana. P. Rao. A and Rao, S.N. (1999) Study on degradation of water quality of Kolleru Lake Ind. J.env health. 41 (4), 300-311

[3] Gill, S.K et.al.. 1993. Phytoplankton and physicochemical parameter examination of river Sutlej, Indian J.Env. prot. 13 (3), 171-175.

[4] Pandey. T.K and G.N. Pandey 1980 physico-chemical characteristics of river Ganga at Kanpur. J.Asst. Engr. India 60;27-34

[5] Sanjay, et.al. 1990 Soruces and distribution of heavymetals in the abiotic components of a polluted urban stream in Bhopal, Indian J. Env. Prot. 10 (8) 600-603.

[6] Athappan P.R., K. Sethuraman and K. Kannan 1992. A study on the pollution of river Vaigai at Madurai. Indian J.Env. prot. 12 (1); 818-823.

[7] Madhystha. M.N., I.J. Rao and hosetti 1996 studies on some heavy metals in Netravathi river, Indian j.Env Health. 38 (3); 181-187.

[8] Sreenivasa Rao, A.et.at 1999, Studies of degradation of water quality of Kolleru lake, Indian J.Env. Health. 41 (4); 300-311.
[9] Doctor P.B. et.al. 1996, physico-chemical and microbial analysis of dye contaminated river water (Bhadar) Indian J.Env. Health. 40 (1)' 7-14.

[10] Jain P. 2009 sickYamuna - sick Delhisearhing a correlation peace institute charitable trust.

[11] Anil Kumar Mishra (2010). A river about to die. Yamuna. Journal of water resource and protection, vol 2 No 5 (2013)

[12] Manenderkaurdhillon, George M.P., Sandeep Mishra, water quality of river Yamuna-Delhi stretch, International journal of environmental sciences, vol 3 (2013).

[13] Fulekar, M.H. and J.M Dave 1983, physico-chemical study of ash effluents in Yamuna river Int. J.env. studies $21 ; 179$.

[14] APHA, AWWA, WEF1995, standard methods for the examination of water and waste water $\left(19^{\text {th }} \mathrm{ed}\right)$ American public health Association. Washington. D.C. 2005.

[15] Chakraborty D. et.al. 1987, Determination of trace metals in natural waters at nanogram per litres levels by electro thermal atomic absorption spectrometry after extractions with NDDC Anal chem. Acta. 196;23-31.

[16] Subramanian. K.S. and J.C. Menager 1979 Ammonium graphite furnace atomic absorption system for some trace metals in drinking water Int. J.Env. Anal chem 7;25-40.

[17] Sharma D.Kansal, A (2011), water quality analysis of river Yamuna using water quality index in the national capital territory. India (2000-2009) applied water science, 1(3-4), PP 147-157.

[18] CPCB, Central pollution control board (2004), report on status of sewage and sewage treatment plants in Delhi.

[19] CPCB, Central pollution central board (2006), Report on water quality status of Yamuna river 1999-2005.

[20] Chadtrik Rout, (2017) Assessment of water Quality. A case study of river Yamuna, International Journal of earth sciences and Engineering, 10 (02), 398-403, 2017, DOI;10.21276 /ijee. 2017,10.0239.

[21] Yadav. V. Khandegar (2019), Dataset on assessment of River Yamuna, Delhi, India using indexing approach, data in brief 22 (2019)1-10.

[22] Akpor, O.B, Otohinoyi, D.A. Olaolu , T.D and Aderiye, BI, (2014), Pollutants in wastewater effluents; Imparts and Remediation processes, International Journal of Environmental research and earth Science, vol3, No3, pp-050-059, March 2014.

[23] C.Sharma, R. Jindal, Udaybhan Singh, A.S. Ahluwalia (2017), Assessment of water quality of river study , Punjab (India), Sustain-water resour, Manag, DOI 10.1007/s40899-017-0173.

[24] ArumaUpadhyay, M. Chandrakala, physico-chemical analysis of Kaveri river water in the pre-monsoon season in Karnataka, India, IJLTEMAS, vol III Issue ix, September 2014. ISSN2278-2540.

[25] Bilal Bhat, SaltanatParveen, Taskema Hassan, Seasonal assessment of physicochemical parameters and evaluation of water quality of river Yamuna, India, Advances in Environmental Technology 9-4(1), 4199,2018 
[26] Ranju Sharma, NgangbamSarat Singh, Dileep K Singh (2020), Impart of heavy metal Concentration and seasonal variations on enzyme's activity of Yamuna river soil in Delhi and NCR, Applied water science 10(3), 1-8, 2020.

[27] Rachana Singh, MayurManglik, Abhinav Srivastava (2015), physico-chemical and statistical Assessment of water quality of river Yamuna in Mathura-Agra Region International Journal on environmental sciences 6(2), 217-225, July-December-2015,(ISSN No-0976-4534).

[28] J.Pandey, R. Singh Heavy metal in sediments of Ganga River UP and down stream urban influences (2017) Applied water science 7(4), 1669-1678, 2017.

[29] E Siddiqui, J Pandey, Assessment of heavy metal pollution in water and surface sediment and evaluation of ecological risks associated with sediment contamination in the Ganga River-A basin-scale study, environmental Science and pollution Research 26(11), 10926-10940, 2019. 